\title{
A Salomé de Oscar Wilde: Véus, espelhos e decapitações na Belle Époque ${ }^{1}$
}

\section{Oscar Wilde's Salome: Veils, mirrors and beheading in the Belle Époque}

\author{
Maria Cristina Franco Ferraz \\ Professora Titular do Programa de Pós-Graduação em Comunicação e Cultura da Universidade Federal do Rio de Janeiro (ECO/ \\ UFRJ), Doutora em Filosofia pela Universidade de Paris I-Sorbonne, Mestre em Letras pela PUC-RJ, pesquisadora do CNPq. \\ $<$ mcfrancoferraz@gmail.com>
}

Louise Ferreira Carvalho

Doutoranda do Programa dePós-Graduação em Comunicaçãoe Cultura da UniversidadeFederal do Rio de Janeiro (ECO/UFRJ), Brasil. $<$ louisecarvalho1@hotmail.com>

\section{RESUMO}

No final do século XIX, assistiu-se, na cultura ocidental, a uma proliferação obsessiva do tema bíblico de Salomé e da decapitação de João Batista, investigada neste artigo ensaístico a partir da peça Salomé (1893), de Oscar Wilde. A disseminação desse episódio na modernidade já laicizada pode ser lida como um dos indícios mais enfáticos da insistência da época em explorar temas pulsantes: o desejo, a sexualidade, a crise da identidade e da suposta coesão do "eu". $\mathrm{Na}$ esteira de Nietzsche, a obra de Wilde realiza um interessante jogo de véus, de máscaras e de espelhos, elevando o falso a sua mais alta potência. Retomando trechos da peça, ressaltaremos os perigos do olhar e das pulsões que levaram a subjetividade moderna a "perder a cabeça".

\section{ABSTRACT}

At the end of the 19th century, people could attend to the biblical theme of Salome and the beheading of John the Baptist, that generated an obsessive proliferation in Western culture. The dissemination of this episode in a secular modernity resonates some topics introduced in European thought, such as desire, sexuality, the crisis of identity and of the self's supposed unity. Based on Nietzsche's "power of the false", this essay explores Oscar Wilde's Salome and the interplays it establishes between veils/masks and mirrors. It also analyses some passages of the play which emphasize the dangers of direct gaze and of the drives that led modern subjectivities to "lose their heads".

Keywords: Mirror. Beheading. Modern culture.

Palavras-chave: Espelho. Decapitação. Cultura moderna.

Contrapondo-se à tradição clássica da harmoniosa imagem bidimensional do corpo, estimada pelas proporções justas e pelos traços essenciais do homem vitruviano, irrompeu no século XIX uma negação impiedosa desses contornos antropomórficos, espelhamento do divino. Em um momento histórico turbilhonar, silhuetas corpóreas, geométricas e contemplativas foram dando lugar a uma avalanche de corpos fragmentados, desconstruídos e decapitados, presentes tanto na cultura letrada e na arte pictórica quanto nos campos de batalha e nas mecanizadas engrenagens urbanas (Singer, 2001). A violenta

1 Pesquisa financiada pelo Conselho Nacional de Desenvolvimento Científico e Tecnológico (CNPq). 
fragmentação de um "eu" ancorado na integridade do corpo repercute, por sua vez, incertezas e novas matrizes instauradas no pensamento ocidental, dentre as quais podemos assinalar a crise do modelo de identidade herdado do platonismo, a deformação da figura humana e a própria emergência da psicanálise.

Em meio a esses vórtices, um tema bíblico retorna com renovado frescor, em uma cultura laicizada, fornecendo um material fértil para se investigarem questionamentos identitários e visadas antimetafísicas que se insinuaram então na filosofia ocidental. Como expressão direta e seminal dessa tendência filosófico-cultural, destaca-se a peça de teatro Salomé, de Oscar Wilde. A insistência do tema e suas versões nos convida a explorar algumas pistas acerca do sentido histórico da releitura oitocentista do tema bíblico, realçando o jogo de véus e de máscaras bem como a lógica de espelhamento - ainda que deformante - nela refletida.

Publicada em 1893, um ano após sua censura nos palcos ingleses, Salomé foi apenas encenada em 1896, quando o autor já se encontrava encarcerado. Wilde jamais pôde testemunhar o estrondoso sucesso da peça, pois faleceu em 1900, cinco anos antes de Richard Strauss adaptá-la em uma ópera que se introduziu no repertório de importantes companhias líricas do mundo. $\mathrm{Na}$ releitura wildeana, o personagem João Batista cede o protagonismo aos movimentos lascivos da princesa Salomé, uma sedutora femme fatale que encarna a sensibilidade e a intensidade dos conflitos modernos em plena Belle Époque, especialmente expressas em uma dança vibrátil que antecipa um pedido funesto: a cabeça de Batista. Em um longo ato que constitui a totalidade da peça, as tensões entre razão e desejo, homem e mulher, rosto e máscara, essência e aparência são elevadas à sua mais alta potência, trazendo à cena os riscos e perigos do olhar e o instigante tema do anteparo protetor de espelhos, máscaras e véus. Celebra-se em cena o poder (e os riscos) da sedução e da aparência.

No século XIX, a peça de Wilde foi apenas uma das muitas obras que tematizaram a princesa Salomé e a decapitação de João Batista. A persistência desse episódio, que se estendeu até meados do século seguinte, é no mínimo curiosa: entre 1840 e 1920, estima-se que cerca de 2.789 obras foram geradas pelo tema na coleção francesa (Janes, 2005, p. 98). A arte e a cultura letrada brasileiras, inspiradas sobretudo pelo conto "Herodíade" (1877), de Gustave Flaubert, pela peça Salomé (1893), de Oscar Wilde, e pelo poema de mesmo título (1895) de Eugênio de Castro, foram também "perpetradoras" de Salomés (Pennafort, 1960, p. 9). Durante a primeira metade do século passado, a ardente dançarina foi pintada por artistas plásticos brasileiros tais como, para citar apenas alguns exemplos, Rodolpho Amoedo, Oscar Pereira da Silva, Sotero 
Cosme e Victor Meirelles. Trata-se, portanto, de um fenômeno significativo que se alastrou pela Europa e nas Américas, ecoando até mesmo nos dias de hoje. ${ }^{2}$

A cultura moderna oitocentista efetua nesse episódio bíblico uma vertiginosa volta do parafuso, em especial na versão de Oscar Wilde, que constitui o foco central deste ensaio. Além de seu enredo, a trajetória da peça possui uma história fascinante que merece ser mencionada. No prefácio à obra Salomé, o jornalista Robert Ross, amigo de Wilde, afirma que o escritor inglês se inspirou em uma série de pinturas realizadas por Gustave Moreau (que dedicou mais de setenta quadros ao tema) e no conto de Flaubert, publicado alguns anos antes (Ross citado por Wilde, 2014, p. 3-5). Contudo, embora ambos os autores se refiram ao nome hebreu de João Batista, "Jokanaan", Wilde e Flaubert elaboram versões muito distintas da mesma passagem da Bíblia. Escrita em francês no inverno de 1892, a peça começara a ser ensaiada no Palace Theatre pela atriz Sarah Bernhardt, quando foi censurada com base em uma antiga lei que proibia a representação teatral de episódios bíblicos. No ano seguinte, Saloméfoi traduzida para o inglês por Lord Alfred Douglas, com ilustrações de Aubrey Beardsley, que nela produziu um de seus trabalhos mais relevantes.

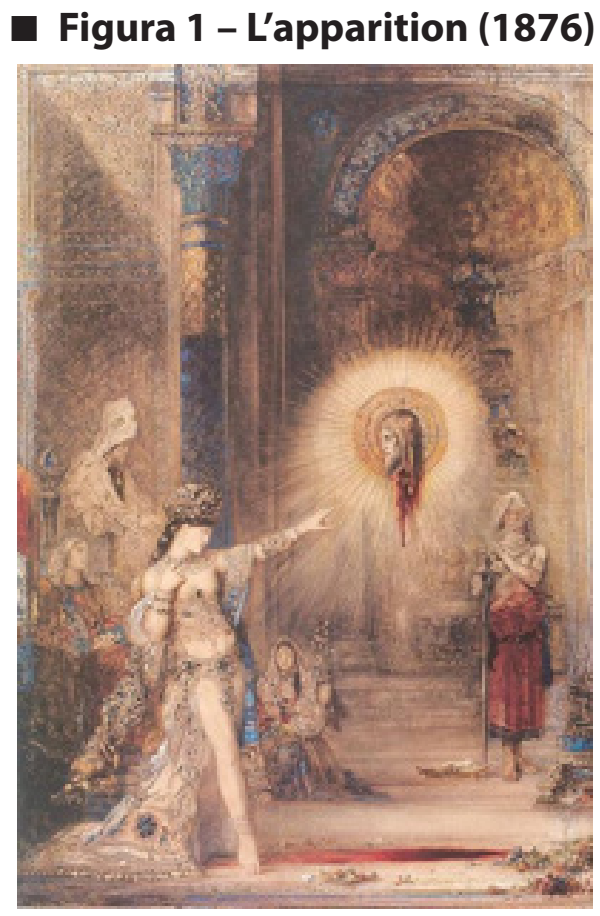

Autor: Gustave Moreau. Fonte: Biblioteca de imagens do Musée d'Orsay, Paris

2 Cabe citar, neste ponto, o filmeWilde Salomé (2011), dirigido por AI Pacino. Nesse filme documentário, Pacino busca conhecer Oscar Wilde como escritor e pessoa, viajando ao deserto de Mojave, à Irlanda e ao Reino Unido. Enquanto isso, dirige e atua a peça Salomé (no papel do Rei Herodes), apresentando aos espectadores do filme os bastidores de sua montagem. 
A censura pode ser relacionada ao tema dos perigos do olhar, que atravessa a peça, apontando uma primeira pista para nossa investigação. No final do século XIX, tal proibição apresenta-se como sintomática no que tange às tensões entre moral e lei no fervilhar da modernidade, bem como no que concerne às pulsões do corpo que o momento histórico parecia deflagrar. Para dimensionarmos tais conflitos, faz-se necessário, inicialmente, resumir o entrecho do drama. Com diálogos intensos perpassados por fino humor, a peça nos situa no Palácio de Herodes, em uma noite banhada pela luz do luar durante a qual se realiza um festim. A bela e jovem princesa Salomé, que captura o olhar e o desejo de todos os presentes, é indiferente aos de Jokanaan, por quem ela se apaixona. Após atender aos insistentes pedidos do rei Herodes, seu padrasto, Salomé executa a dança dos sete véus, levando-o ao delírio. O corpo bailarino da princesa lasciva, rejeitado pelo profeta, é então usado por ela mesma como moeda de troca para pedir ao rei a cabeça daquele que se recusava a mirá-la. Serão os lábios dessa cabeça decepada que Salomé conseguirá finalmente beijar. Ante o terror inédito do ato macabro, Herodes recusa-se a olhar para a cena, apaga as luzes e ordena, por fim, a execução de Salomé.

- Figura 2 - The Climax (1893)

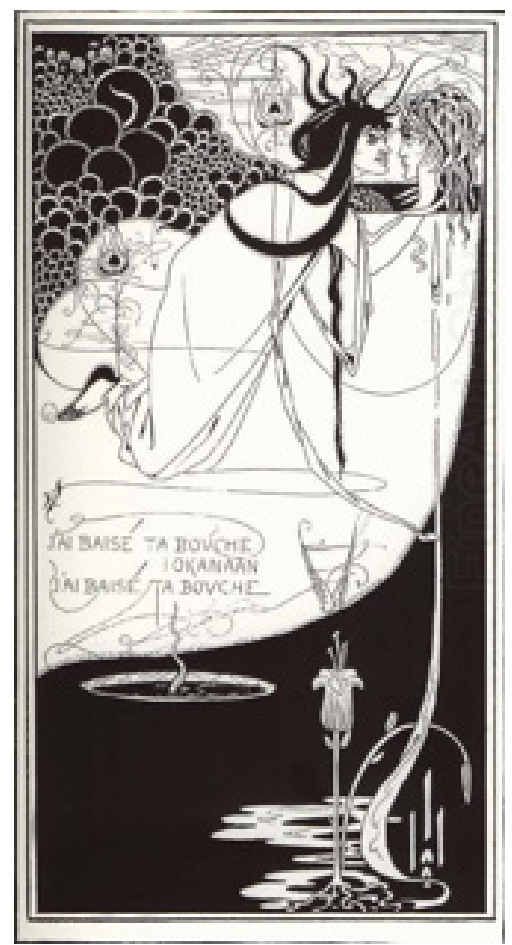

Aubrey Beardsley. Fonte: Ilustração do livro Salomé (2014) 
Cabe, de saída, recuar estrategicamente ao tema da emergência da "sexualidade" na época moderna. Conforme sublinhou Michel Foucault, o século XIX correspondeu, na cultura ocidental, a um momento ambíguo no que concerne ao erotismo e ao sexo. No primeiro volume de $A$ história da sexualidade, o filósofo francês analisa as relações de poder-saber-prazer que passaram a vigorar na sociedade moderna, procurando desvendar o tipo de subjetividade produzida nas profundezas de uma interioridade psicológica balizada pelo desejo (Foucault, 2006). Foucault desmonta a"hipótese repressiva”, que afirma ter ocorrido, ao longo da modernidade ocidental, um progressivo desconhecimento do sujeito a respeito de sua própria sexualidade ou de seu desejo por conta da repressão sexual. O filósofo mostra que, ao contrário do que crê o senso comum e se cristalizou teoricamente (Marcuse, 1975), manifestouse uma insistente "vontade de saber" a esse respeito. Passou-se a produzir, no plano geral da cultura, um saber excessivo acerca do que se cunhou como "sexualidade". A própria psicanálise, que estabeleceu o fundamento racional de um saber acerca do desejo, teria integrado essa produção teórica.

Foi precisamente a sexualidade de Salomé que constituiu o maior objeto de interesse na atmosfera fin-de-siècle. A personagem foi intensamente erotizada nas pinturas e narrativas do século XIX, ensejando versões que destoam curiosa e radicalmente de suas próprias fontes. Com efeito, as descrições da dança dos sete véus realizadas nos evangelhos de São Mateus e de São Marcos estão longe de sugerirem lubricidade ou conotação sexual. A erotização da princesa parece encontrar-se em sintonia fina com a reformulação moral operada na modernidade e com o que recentemente se chamou de "pornificação do olhar" (Sibilia, 2015, p. 192). Insinuando-se desde o final da Idade Média, a pornificação do olhar teria se intensificado desde o século XVIII, em consonância com os avanços do capitalismo e da ética protestante. Conotações sagradas ligadas ao corpo foram sendo, desde então, paulatinamente desativadas, dando lugar à captura das imagens corporais tanto pela indústria pornográfica quanto pelo saber anatômico (Sibilia, 2014, p. 40). Essa "pornificação" de Salomé não impediu, entretanto, que sua sexualidade permanecesse de algum modo turva e difusa, até mesmo indeterminada, suscitando controvérsias. Conforme afirma Eliane Robert Moraes, “o que ficou oculto por baixo de seus decantados véus foi justamente o sexo, tendo se tornado, por isso mesmo, objeto de intensa especulação" (Moraes, 2012, p. 31). Seja nas gravuras de Beardsley, nas pinturas de Moreau ou no conto de Flaubert, a virgem aparece ao mesmo tempo assexuada e lasciva. Essa ambiguidade sexual integra o mecanismo de funcionamento descrito por Foucault: um "querer saber" discursivo insistente 
sobre o sexo, alçando o desejo a um conceito teórico pregnante e saturando sexualmente tanto os corpos quanto discursos e saberes.

O ocultamento do sexo de Salomé, apontado por Eliane Moraes, ganha dimensões suplementares uma vez articulado a uma figura da mitologia grega que também apresenta uma sexualidade indefinida: Baubó. Vale a pena retomar esse personagem, que irá acrescentar novas nuances a nosso tema. Segundo Jean-Pierre Vernant, em A morte nos olhos, Baubó ora aparece como um espectro noturno, uma espécie de ogro assemelhado às divindades infernais, ora como uma velha bem-humorada e bondosa (Vernant, 1988, p. 40). É sob essa última forma encarnada que ela recebe Deméter, a desesperada mãe de Perséfone, que procurava, por todo o mundo grego, sua filha, raptada por Hades. Conta a lenda que, para atenuar o sofrimento de Deméter, Baubó levantou as saias para mostrar seu sexo. Tal gesto conseguiu provocar na deusa aflita uma explosão de riso, liberando-a de sua tristeza. Em sua análise, que se estende às representações pictóricas do episódio, Vernant assinala que a personagem é frequentemente reduzida a um rosto que, por sua vez, é simultaneamente um ventre. Segundo o autor, o que Baubó mostra a Deméter é "um sexo disfarçado de rosto, um rosto em forma de sexo; poderíamos dizer: o sexo feito de máscara" (Vernant, 1988, p. 40).

Não por acaso, o filósofo alemão Friedrich Nietzsche recorreu a Baubó tanto para corroer a oposição metafísica superfície/profundidade como para valorizar (em seus termos, "transvalorar") o decoro e o pudor. A fim de enriquecer a rede de articulações aqui tramada para a análise de Salomé, remetemos neste ponto ao final do prólogo à Gaia Ciência no qual o filósofo ressalta seu afastamento com relação à "vontade de verdade a todo custo", recorrente na história do pensamento ocidental. Essa "vontade de verdade" corresponderia à necessidade de desvelar - ou de desnudar - o que estaria supostamente "por trás" (de máscaras, de véus), oculto, ou velado. Estaria portanto ligada a uma verdadeira obsessão em perseguir e descobrir o que se manteria supostamente oculto pelos véus da aparência. Nietzsche contrapõe-se a esse "amor à verdade" com a seguinte afirmação: "Já não acreditamos mais que a verdade continue verdade quando se lhe retira o véu" (Nietzsche, 2012, p. 14). Em seguida, o filósofo ressignifica dois valores associados à mulher no século XIX, o decoro e o pudor, que passam a remeter à pura aparência sem uma "essência" por trás. Retirando a etiqueta e a virtude, respectivamente, do campo da mundanidade e da moral, Nietzsche as insere no movimento de sua filosofia. Nessa torção, o pudor implica aderir de modo definitivo a toda espécie de véu, de máscara, a tudo o que serve para encobrir; o decoro equivale a ater-se às sedutoras aparências - como a própria Salomé. 
A abordagem nietzschiana revira pelo avesso dicotomias que pautavam a construção moderna de identidade, tais como essência (verdadeiro) e aparência (falso), ser e parecer, interior e exterior, profundidade e superfície. Sua estratégia é a de generalizar o polo metafisicamente desqualificado (por exemplo, só há "aparências", véus, máscaras), provocando uma superação do solo mesmo em que se fabricavam dualismos. Para arrematar esse gesto, no final do prólogo à Gaia ciência, Nietzsche avança a seguinte sugestão: "Talvez a verdade seja uma mulher que tem fundos/razões (Gründe) para não deixar ver seus fundos/suas razões (Gründe)?" (Nietzsche, 2012, p. 15-16). Ora, os sedutores véus de Salomé e seu desejo macabro não apontariam igualmente para uma ausência de fundo no duplo sentido ressaltado por Nietzsche?

Com efeito, na passagem de Gaia ciência, o termo alemão Gründ(e) significa tanto solo, chão quanto razão ou fundamento. A referência aos "fundos" femininos também é clara, em um sentido trivial, irônico, malicioso (Ferraz, 2010, p. 179). A relação entre verdade e mulher, além da valorização da superfície, do pudor e dos véus, conflui para a seguinte hipótese: "Talvez o seu nome [da verdade], para falar grego, seja Baubó?"'(Nietzsche, 2012, p. 15). Nietzsche associa mulher e verdade no sentido da esquiva a todo fundo ou fundamento, atendose à superfície, à aparência e aos enigmas, em um movimento que visa a afastarse da "vontade de verdade" a todo preço. A gargalhada liberadora de Deméter, suscitada pela falta de fundo(s) da superfície-verdade-mulher, encarnada por Baubó, sela o afastamento com relação a qualquer modelo estabelecido em um solo fixo, a perspectivas dogmatizantes e às rigorosas malhas da identidade dominante (homem-branco-ocidental etc.).

Apostando na mais alta potência do falso e inaugurando um regime que se esquiva à pretensão de alcançar um suposto "fundo", Nietzsche sublinha que, por trás dos véus, há sempre outros véus; por trás de máscaras, outras máscaras, ao infinito. Esse regime antimetafísico parece expressar-se nos sedutores véus da Salomé wildeana. Embora os véus sejam numericamente finitos (sete) e revelem a nudez final, a dança mesma realça aparências que se velam e desvelam; nesse jogo, fascina e seduz, açulando o desejo, em um turbilhão acionado pelo "sem fundo", pelo "não fundado". Prova disso é que, quando a nudez emerge no regime dos véus instaurado na peça, esgota-se a cena, o jogo. Cessa a dança.

Voltemos ao aspecto mais inusitado da interpretação de Vernant, de certo modo tributária da referência a Nietzsche. Para Vernant, o gesto obsceno de Baubó evidencia uma "máscara do sexo", isto é, um sexo disfarçado de rosto e um rosto em forma de sexo. Tal máscara transmuta o horror em humor, sinalizando a ambivalência entre o terrificante e o grotesco na própria categoria do monstruoso (Vernant, 1988, p. 103). Nessa esteira de pensamento, os dilemas 
entre fascínio e risco, sedução e horror, riso e medo, êxtase e dor e, sobretudo - ressoando o filósofo Georges Bataille -, erotismo e morte compõem a zona de indeterminação e de ambiguidade na qual se situa Salomé. Na ominosa aproximação entre amor e morte, Wilde exprime paixões que se consomem a si mesmas, gerando vórtices de pulsões que colocam em risco a coesão do "eu", fazendo "perder a cabeça". Aciona-se, então, conforme veremos adiante, um vertiginoso dispositivo de decapitações em série.

A partir dessa teia de relações, investiguemos mais detidamente o temor ao olhar evidenciado na obra e suas implicações. Nos momentos iniciais da peça, o jovem sírio Narraboth elogia a beleza da princesa Salomé na noite do festim e é imediatamente repreendido nestes termos pelo escudeiro da rainha Herodíade: "Você está sempre olhando para ela. Você olha demais para ela. É perigoso olhar para as pessoas dessa maneira. Algo terrível pode acontecer"3 (Wilde, 2014, p. 8). O perigo, o medo e o terror não podem ser dissociados da potência do olhar voltado tanto para coisas como para pessoas -, ecoando o que bem ressaltou um xamã citado por Viveiros de Castro: "O maior perigo na vida é o fato da comida humana consistir inteiramente de almas" (Bodenhorn citado por Castro, 2011, p. 894). O antropólogo brasileiro salienta que os ameríndios não deixariam seus olhos serem capturados pelo olhar alheio de um espírito maligno; em vez disso, simplesmente olhariam para o outro lado (Castro, 2011, p. 904). Como, aliás, o fez Jokanaan na peça de Wilde. Se os homens se alimentam sobretudo de almas, é necessário ficar atento aos efeitos de olhares diretos, como também aos riscos quando se é olhado. Vale lembrar que em algumas culturas, como a francesa, na qual é incômodo olhar diretamente um desconhecido, existe inclusive um verbo especial que bem expressa esse temor. Trata-se de "dévisager", algo diverso do português "encarar", pois o lance de olhos, conforme o que se cristalizou na língua francesa, tem o efeito mais radical de retirar ou de eliminar o que se compôs como um rosto. Equivaleria, literalmente, a algo como "desrostar".

Sem conseguir desviar os olhos de Salomé, Narraboth é advertido ao menos seis vezes pelo amigo escudeiro a respeito do perigo (e, portanto, da potência) do olhar, antecipando o desfecho da tragédia. O jovem sírio, no entanto, não é o único atraído pela princesa e censurado por essa conduta. Fugindo do festim, Salomé entra no terraço do palácio de Herodes e questiona: “Por que o Tetrarca olha para mim a todo tempo com seus olhos de toupeira debaixo de suas pálpebras agitadas? É estranho que o marido da minha mãe me

3 Tradução dos autores. No original, em inglês: "You are always looking at her. You look at her too much. It is dangerous to look at people in such fashion. Something terrible may happen". 
olhe assim"4 (Wilde, 2014, p. 12). Inevitável assinalar, de passagem, a presença do tema - tabu - do incesto na cultura ocidental, igualmente vinculado a certa moral sexual ancorada no cristianismo (Foucault, 1998, p. 16). Nitidamente incomodada, Herodíade, mãe de Salomé, reprova diversas vezes a insistência do rei em olhar sua filha. No texto são utilizados verbos da língua inglesa que variam do mais trivial "look" (olhar) até o mais focado "gaze" (olhar fixamente, encarar).

Embora seja ela o alvo especial dos olhares, Salomé tampouco resiste à tentação de admirar seu objeto de desejo e faz de seu olhar moeda de barganha. No terraço, a princesa ouve um grito que atrai sua atenção. Descobre então que Jokanaan se encontra preso em uma cisterna e, imediatamente interessada por esse homem temido pelo próprio rei, lança ao jovem sírio uma proposta irresistível: caso este a deixe falar com o profeta, Salomé promete no dia seguinte olhar para o jovem apaixonado. Diz: "[...] eu vou olhar para você através dos meus véus de musselina, eu vou olhar para você, Narraboth, e talvez eu vá sorrir para você" ${ }^{5}$ (Wilde, 2014, p. 14). Nesse momento, a princesa negocia seu olhar, mediado por um véu, que intensifica ainda mais a sedução - e acrescenta o sorriso como um brinde. Conforme mencionado, em culturas ameríndias para as quais a alma é o principal alimento dos homens, a captura se dá pelo olhar (Castro, 2011, p. 894). Embora o Ocidente tenda a denegar essa força, em certas subculturas mediterrâneas e brasileiras persiste a crença na eficácia do "mauolhado", que pode de fato ter consequências temíveis (Gil, 2004). Na esteira dessas visadas, o próprio Herodes explicita, na parte final da narrativa, o tema da potência avassaladora do olhar direto sobre coisas e pessoas, fazendo intervir a função apotropaica ${ }^{6}$ dos espelhos:

É verdade, olhei para você toda essa noite. Sua beleza me perturbou. Sua beleza me perturbou gravemente, e olhei demais para você. Mas não olharei mais para você. Não devemos olhar para coisas ou para pessoas. Deve-se olhar apenas para espelhos, pois o que os espelhos fazem é somente nos mostrar máscaras ${ }^{7}$ (Wilde, 2014, p. 37).

4 No original, em inglês: "Why does the Tetrarch look at me all the while with his mole's eyes under his shaking eyelids? It is strange that the husband of my mother looks at me like that". Cabe ressaltar que o processo de intensificação de olhares "pornificados" não deixaria de identificar aqui, atualmente, sintomas de incesto e de pedofilia.

5 No original, em inglês: "[...] I will look at you through the muslin veils, I will look at you, Narraboth, it may be I will smile at you".

6 Do grego apotrepein ("afastar-se"), que tem poder de afastar uma desgraça ou uma influência maléfica.

7 No original, em inglês: "It is true, I have looked at you all this evening. Your beauty troubled me. Your beauty has grievously troubled me, and I have looked at you too much. But I will look at you no more. Neither at things, nor at people should one look. Only in mirrors should one look, for mirrors do but show us masks". 
Essa enigmática fala do rei aciona um jogo de aparências ao infinito, uma trama entre espelhos e máscaras, ambos véus mediadores do temível olhar direto. A metáfora do espelho arraigou-se no mundo ocidental em várias camadas e níveis. Alguns desses sentidos foram remetidos a modelos de identidade, a formas de constituir o "eu" em relação ao olhar do outro, mas também a regimes de introspecção reflexiva e ao jogo mimético. Lembremos uma frase colocada em epígrafe ao capítulo 13 do livro O vermelho e o negro (1830), de Stendhal: "Um romance é um espelho que se passeia pelo caminho" (Stendhal, 2010, p. 105). Durante o século XIX, boa parte da ficção propôs espelhos romanescos, muitas vezes deformantes, da cultura moderna. Salomé é um desses casos. Espelho voltado sobre si, a peça não deixa de refletir a (sobre a) função protetora, apotropaica, de espelhos e, nesse sentido, do próprio mimético.

Em uma nota de rodapé à peça editada, Robert Ross afirma: "Wilde costumava dizer que 'Salomé' era um espelho em que cada um podia se ver refletido: o artista, a arte; o tolo, a tolice; o vulgar, a vulgaridade" ${ }^{8}$ (Ross citado por Wilde, 2014, p. 5). Não surpreende, então, que a peça tenha sido censurada: os censores viram obscenidade porque eram, eles mesmos, obscenos. Ou seja: exerciam seu olhar pornificador. O que se vê ou lê é sintomático de valores sociais partilhados; em suma, lê-se apenas a máscara que se colou no próprio rosto, a máscara que se é: eis a função reveladora do espelho ficcional wildeano. Se o espelho apotropaico protege das ameaças do olhar, as máscaras que nele aparecem equivalem a uma proteção e, ao mesmo tempo, a um espelhamento de valores morais socialmente assentados. Essa dupla direção se insere no regime das aparências, que não prometem qualquer essência verdadeira por trás.

Para compreendermos o estatuto das máscaras na modernidade, ampliando a investigação, remeteremos brevemente à perspectiva teórica de Richard Sennett apresentada em O declínio do homem público. No livro, o autor examina a invenção da ideia moderna de "intimidade", ressaltando as reconfigurações das esferas do público e do privado na passagem do século XVIII para o XIX (Sennett, 2014). No século XVIII, a esfera pública e propriamente política brilhava nas grandes cidades europeias em expansão, sobretudo Paris e Londres. Naquela época, as relações impessoais e a teatralização estavam envoltas em uma valorização positiva. No século seguinte, ao mesmo tempo em que se dá um esvaziamento do âmbito público propriamente político, que começa a ganhar um tom cada vez mais ameaçador, infla-se a esfera privada, protegida no aconchego do lar burguês. Sennett associa esse esvaziamento ao

8 No original, em inglês: "Wilde used to say that 'Salomé' was a mirror in which everyone could see himself. The artist, art; the dull, dullness; the vulgar, vulgarity". 
regime da "autenticidade", baseado na crença de que a própria personalidade seria um tesouro interior capaz de se trair e revelar no espaço público, sob os rigores das normas sociais. O autor assinala, assim, a passagem do "regime da máscara" (século XVIII) para uma desvalorização das máscaras, por elas supostamente esconderem um rosto autêntico que deveria ser protegido do olhar de estranhos. Esse rosto "verdadeiro", pretensamente mais valioso que qualquer disfarce mundano, deveria furtar-se à cena pública, o que correspondeu à produção de rostos "neutros", de novas máscaras ilegíveis, em circulação anônima nos centros urbanos em frenética expansão. ${ }^{9}$

Sennett nos auxilia a dimensionar a problemática da máscara do ponto de vista histórico. Já no campo filosófico, a desqualificação da máscara ganhou outros contornos desde o limiar da filosofia ocidental hegemônica. Relaciona-se à condenação do mimético e à invenção do polo de oposições metafísicas que balizaram a filosofia socrático-platônica. Para fundar esse campo, Platão rivalizou com seus adversários mais imediatos na polis grega - a sofística, a retórica, a poesia e a pintura -, utilizando uma tática que consistiu em colocá-las em estreita relação umas com as outras, para que determinada crítica a respeito de uma recaísse sobre todas as demais. As oposições forjadas - essência/aparência, verdadeiro/falso, ser/parecer -, além de consolidarem a lógica da contradição, circunscreveram as práticas discursivas condenadas no campo do falso, da mentira, do não ser, do engano, capazes de persuadir, de adular os sentidos de um modo totalmente descompromissado com a verdade e com o bem. Desse momento em diante, o reino do falso (pseudos) será colocado em oposição ao "verdadeiro" (alethes), tornado objeto exclusivo da filosofia (Ferraz, 2009).

Para Platão, na arte do poeta e nas performances do rapsodo e do ator ocorre o risco da desapropriação e da perda de identidade, ambos associados ao campo do mimético. A máscara é radicalmente condenada na filosofia socrático-platônica, pois o uso de múltiplas máscaras, masculinas e femininas, de diferentes idades e condições sociais, faz com que essas figuras sejam compreendidas como ameaçadoras para a unidade harmônica da alma (Ferraz, 2009). Manifesta-se, nessas artes, um pacto com o regime de alteridade, com o outro, diferente do "eu". O risco de desapropriação implicado pelo mimético sugere um temor ante a ameaça à coesão do "eu", aos riscos inerentes à subversão da harmoniosa hierarquia das almas, bem como perante a potência realizadora das máscaras. Todos esses efeitos perniciosos, proporcionados pelo "engano" e pela "mentira", contaminariam a alma e a libertariam do governo da razão: eis,

9 Inevitável lembrar aqui o conto seminal de Edgar Allan Poe, "O homem da multidão" (1840), que sintetiza a nova experiência de multidão, novos regimes de percepção e de atenção, múltipla e fragmentada, bem como o gosto pelo enigmático no espaço anônimo (Poe, 2008). 
em suma, sintetizado o temor platônico ao mimético, à ficcionalidade e à perda de si. Uma vez colocada sobre o rosto, a máscara suscita e efetua no corpo novas e inesperadas metamorfoses.

Nesse contexto, a máscara será associada ao fingimento, inserida no reino do mimético e do simulacro. Conforme denunciado por Nietzsche, esse gesto revela que metafísica e moral estão intimamente imbricadas: práticas associadas ao terreno da ficcionalidade, do não sério, do fingimento passam a ser consideradas como forças sedutoras aptas a desviar do caminho da ascese em direção ao bem e à verdade. Em uma visada crítica, no parágrafo 189 de Além do bem e do mal, o filósofo alemão afirma, em tom provocativo:

Por trás de uma caverna, uma caverna ainda mais profunda - um mundo mais rico, mais estranho e mais vasto além de uma superfície, um abismo (Abgrund) por trás de cada chão/razão (Grund), por trás de toda "fundamentação" (Begründung) (Nietzsche, 2012, p. 216). ${ }^{10}$

A referência nietzschiana à imagem da caverna nada possui de inocente: remete à alegoria que abre o livro VII de $A$ república. Se a caverna de Platão aponta para uma ascese em direção à iluminação e à verdade, a caverna nietzschiana inviabiliza a instauração de firmes e sólidos "fundamentos". Nessa perspectiva, existem apenas outros fundos, fundos falsos, projetando-se em abismo, produzindo reviravoltas que abalam a segurança de um chão seguro para ancorar certezas, assentar a razão e a crença em identidades estáveis (Ferraz, 2002). Na visada nietzschiana, as máscaras colocadas não podem ser retiradas sem que se arranque junto o que se julgava ser o rosto autêntico e verdadeiro.

Se, segundo a fala do Herodes de Salomé, os espelhos, deformantes por excelência, apenas refletem máscaras, instaura-se na peça um jogo paradoxal que torna indecidível a oposição mesma entre verdadeiro e falso, entre essência e aparência. Como afirma o Herodes wildeano, todo olhar deve ser mediado pelo espelho; caso contrário, algo terrível pode suceder. Ao longo da peça, o olhar se mostra cada vez mais potente, desenfreado e perigoso. Voltemos ao drama: o pedido de Salomé a Narraboth é realizado e ela encontra Jokanaan. No entanto, como se o futuro santo intuísse a potência destrutiva do olhar, ele é o único que recusa ser olhado pela princesa: "Quem é essa mulher olhando para

10 Tradução modificada. 
mim? Eu não quero que ela olhe para mim"11 (Wilde, 2014, p. 16). Cada vez mais apaixonada pelo profeta, Salomé pede para tocar seu corpo, seus cabelos e para beijar sua boca. Embora todos esses pedidos sejam negados com rispidez por Jokanaan, que insulta violentamente Salomé e sua mãe, a princesa assegura que irá beijar sua boca. Diante dessa cena, Narraboth, tomado pelo sofrimento de ver sua amada apaixonada por outro, comete suicídio e cai morto entre Salomé e Jokanaan. É sobre o sangue do jovem sírio que, mais adiante, a princesa irá dançar, com pés nus, a dança dos sete véus.

Existe ainda outro elemento que funciona na peça como um espelho deformante: a lua. Com a morte de seu amigo Narraboth, o escudeiro de Herodíade confirma suas funestas previsões: "Eu sabia que a lua buscava uma coisa morta, mas eu não sabia que era ele que ela procurava. Ah! Por que não o escondi da lua? Se eu o tivesse escondido em uma caverna, ela não o teria visto"12 (Wilde, 2014, p. 19). A lua reflete, em diferentes momentos, a mulher e a potência feminina; mais especificamente, como no trecho acima, a própria Salomé. Essa associação se cristaliza desde o início da peça, quando o jovem sírio admira a beleza da princesa e, em seguida, o escudeiro de Herodíade exclama: "Olhe para a lua! Ela parece tão estranha! Ela é como uma mulher emergindo do túmulo. Ela é como uma mulher morta. Você poderia imaginar que ela está buscando coisas mortas"13 (Wilde, 2014, p. 7). A lua funciona como uma imagem distorcida da princesa que, com sua beleza e juventude, teria levando o jovem sírio à morte. A própria Salomé parece falar de si mesma quando olha para a lua, antes de seu encontro com Jokanaan, no seguinte trecho: "Como é bom ver a lua! [...] A lua é fria e casta. Tenho certeza de que é virgem, ela possui a beleza das virgens. Sim, ela é virgem. Nunca se expôs. Nunca se abandonou aos homens, como as outras deusas"14 (Wilde, 2014, p. 12).

Referida como "ela" (she), indicando uma personagem feminina (como na língua francesa, na qual a peça foi escrita), a lua descrita pelo jovem sírio, pelo escudeiro, pelo rei e pela própria Salomé vagueia mostrando diferentes faces; sua instabilidade e variabilidade espelham a princesa. Enquanto o escudeiro de Herodíade vê a lua como pálida e perigosa, Narraboth a descreve como "uma

11 No original, em inglês: "Who is this woman who is looking at me? I will not have her look at me".

12 No original, em inglês: "Well I knew that the moon was seeking a dead thing, but I knew not that it was he whom she sought. Ah! Why did I not hide him from de moon? If I had hidden him in a cavern she would not have seen him".

13 No original, em inglês: "Look at the moon! How strange the moon seems! She is likea woman rising from a tomb. She is like a dead woman. You would fancy she was looking for dead things".

14 No original, em inglês: "How good to see the moon! [...]The moon is cold and chaste. I am sure she is a virgin, she has a virgin's beauty. Yes, she is a virgin. She has never defiled herself. She has never abandoned herself to men, like the other goddesses". 
princesa que tem pequenas pombas brancas no lugar dos pés"15 (Wilde, 2014, p. 7). Salomé, por sua vez, identifica o astro a uma jovem virgem. A visão do rei Herodes é igualmente sugestiva. Após o intenso diálogo entre a princesa e Jokanaan, e o suicídio subsequente do jovem sírio, o rei, a rainha e toda a corte entram no terraço à procura de Salomé. Sem perceber o cadáver de Narraboth, o rei pergunta pela princesa e é imediatamente repreendido pela esposa. Em seguida, profere discurso sobre a lua que vale a pena destacar:

\begin{abstract}
A lua está com um olhar estranho essa noite. Ela não está com um olhar estranho? É como uma mulher louca, uma mulher louca em busca de amantes por todo lugar. [...] As nuvens estão procurando vestir sua nudez, mas ela não vai deixar. Mostra-se nua no céu. Volteia pelas nuvens como uma mulher bêbada... Tenho certeza de que está buscando amantes. Não se contorce como uma mulher bêbada? Ela é como uma mulher louca, não é? ${ }^{16}$ (Wilde, 2014, p. 21).
\end{abstract}

A imagem da lasciva lua voltejando, dançando por entre nuvens como uma mulher nua, louca e bêbada à procura de amantes reafirma a ligação entre o feminino e as intensidades do corpo, irredutíveis ao domínio racional tradicionalmente relacionado ao masculino. Essa implicação mútua entre homem-razão-sol, em oposição à mulher-corpo-lua, reedita uma associação cultural que perdura até hoje no senso comum. Quando dizemos, por exemplo, que alguém é "de lua", nos referimos às variações de humor e de emoções, cambiáveis como as fases lunares. Além disso, por seus ciclos regulares, a lua tornou-se, desde a antiguidade, uma importante referência cultural na linguagem, nos calendários, na arte e na mitologia. Nesse sentido, enquanto a racionalidade é atribuída à cabeça do homem e à iluminação solar, a mulher estaria sob o signo lunar, sujeita às variações das sensações e aos perigos provenientes de suas alterações intempestivas.

A relação sol, cabeça e razão, culturalmente previsível, será alterada por Georges Bataille na primeira metade do século XX. E, como veremos, também ao final da peça Salomé. Para avançarmos na compreensão dessa reviravolta, mencionemos um texto de Bataille intitulado Soleil pourri, publicado em 1930.

15 No original, em inglês: "She is like a princess who has little white doves for feet".

16 No original, em inglês: "The moon has a strange look to-night. Has she not a strange look? She is like a mad woman, a mad woman who is seeking everywhere for lovers. [...] The clouds are seeking to clothe her nakedness, but she will not let them. She shows herself naked in the sky. She reels through the clouds like a drunken woman... I am sure she is looking for lovers. Does she not reel like a drunken woman? She is like a mad woman, is she not?". 
O filósofo menciona uma prática religiosa muito difundida no culto mitríaco do sol, que consistia em colocar um homem nu dentro de uma espécie de fossa coberta de ramos entrelaçados, sobre a qual um sacerdote degolava um touro. $O$ homem recebia uma chuva de sangue quente enquanto o touro mugia e lutava. Tratava-se, nas palavras do autor, de um "simples meio de recolher moralmente os benefícios do sol ofuscante" (Bataille, 1930, p. 174). Eliane Moraes esclarece que, nesse texto, o autor contesta a elevação do espírito, amplamente difundida na cultura ocidental (Moraes, 2012). Afinal, a imagem mais popular do filósofo parece ter sido aquela fixada pelo platonismo: a de um ser que sai da caverna e ascende. O movimento dessa operação filosófica, pautada em valores transcendentes, consiste em se voltar para o princípio (que estaria no alto), em uma operação de ascese e conversão, caminho do platonismo em direção ao conhecimento e ao bem, que iria se expressar igualmente no cristianismo (Deleuze, 2011).

$\mathrm{Na}$ tradição neoplatônica, a forma do sol é glorificada e vinculada às noções de substância e de eternidade. A contrapelo dessa tradição, no culto mitríaco referido por Bataille o sol é tratado de modo violento e não idealizado. Na filosofia batailleana, o astro deixa de ser uma abstração, rompendo a tradição transcendente. Retorna aos excessos de seu fulgor, vinculando-se ao sangue e a forças taurinas, distanciando-se das asceses operadas pelo conhecimento racional; inaugurando, em suma, um novo leque de sentidos: "Pode-se acrescentar que o sol ainda foi mitologicamente expresso por um homem degolando-se a si mesmo e, por fim, por um ser antropomórfico desprovido de cabeça" (Bataille, 1930, p. 174). Não há dúvida, segundo Bataille, de que o touro é uma imagem do sol, mas apenas quando decapitado. Em ruptura com o platonismo e com toda a tradição posterior, os benefícios do sol ofuscante supõem o violento gesto da degolação, rompendo-se o modelo antropomórfico, bem como o domínio da racionalidade e do intelecto humanos. Em Salomé, conforme veremos, a imagem lunar da mulher termina por ceder lugar a uma ofuscante iluminação solar. Quando ocorre a decapitação de Jokanaan, a luz solar é efetivamente mirada: tão brilhante que pode cegar. Não por acaso, no final da peça, reina, vitoriosa, a escuridão, vinculada ao temor.

É interessante notar que, na peça de Wilde, é a mulher que opera cortes. A rainha Herodíade intercepta incisivamente as divagações em torno da lua; Salomé manda decepar a cabeça de um homem. Recorramos, uma vez mais, ao texto. Após ter ouvido a longa rede metafórica, estabelecida pelo rei, entre mulher-lua-desvario, e este ter lhe perguntado se a lua também lhe parecia uma mulher louca, a rainha responde, cortante: "Não. A lua é a lua; isso é tudo"17

17 No original, em inglês: "No; the moon is the moon, that is all". 
(Wilde, 2014, p. 21). Herodíade destrói com essa fala o vínculo de metaforização e de espelhamento entre lua e mulher, lua e Salomé, subvertendo dicotomias implicadas nessas associações culturais (homem/mulher, razão/emoção, sol/ lua). Nesse sentido, aproxima-se da perspectiva elaborada por Bataille. A perda da racionalidade será ainda mais radical no final da peça, quando é enunciado o pedido funesto da princesa.

À diferença de outros escritores que tematizaram o mito de Salomé, como Flaubert e Huysmans, Wilde não nos fornece qualquer descrição da dança dos sete véus. Os movimentos sedutores da princesa ficam a cargo da interpretação do leitor ou do diretor da montagem. Apenas uma indicação redundante nos é apresentada: "Salomé dança a dança dos sete véus"18 (Wilde, 2014 , p. 35). Recobrindo com um véu-pudor a cena da dança, o escritor inglês oferece ao leitor apenas os efeitos dos movimentos bailarinos da princesa, que encantaram entusiasticamente a todos no salão do festim. Herodes pergunta então à princesa o que ela deseja, pois ele lhe dará qualquer coisa, até mesmo metade do seu reino. Para a surpresa geral - e para a alegria de sua mãe -, Salomé não quer saber de joias ou de poder. Pede que lhe tragam, sobre uma travessa de prata, aquilo que pertence ao rei: a cabeça de Jokanaan.

Temendo um terrível infortúnio, Herodes lhe oferece desesperadamente uma ampla diversidade de presentes no lugar da cabeça do profeta. Todas as ofertas são, entretanto, rebatidas por Salomé ríspida e insistentemente: “Dê-me a cabeça de Jokanaan"19 (Wilde, 2014, p. 36-39). Sem outra saída, o rei rende-se ao desejo de sua enteada e afirma que ela é verdadeiramente filha de Herodíade, enquanto ambas celebram, por motivos diferentes, a morte de Jokannan. Nesse momento, a cabeça é destronada para se tornar um fragmento reificado, um reiterado objeto de desejo: "Vá até os soldados e ordene-Ihes irem lá embaixo e me trazerem a coisa que eu peço, a coisa que oTetrarca me prometeu, a coisa que é minha"20 (Wilde, 2014, p. 39, grifos nossos). Ecoando de certo modo a literalidade de "a lua é a lua", a redonda cabeça do homem é reduzida a uma "coisa" exposta sobre a reluzente superfície de uma travessa de prata. Essa "coisa" não parece muito distinta de um fragmento de corpo humano sobre uma mesa de dissecação.

Podemos afirmar que a decapitação de Jokanaan cria uma cabeça-objeto para a qual confluem tanto o desejo quanto a vingança de Salomé. "Bem,

18 No original, em inglês: "Salomé dances the dance of the seven veils".

19 Salomé começa, no entanto, com um pedido: "I ask you the head of Jokanaan" (eu peço a cabeça de Jokanaan); após as desculpas do rei por tê-la olhado demais naquela hoje, insistindo que a princesa pedisse qualquer outra coisa, Salomé exige: "I demand the head of Jokanaan" (eu exijo a cabeça de Jokanaan) e "give me the head of Jokanaan" (dê-me a cabeça de Jokanaan).

20 No original, em inglês: "Go to the soldiers and bid them go down and bring me the thing I ask, the thing the Tetrarch has promised me, the thing that is mine". 
Jokanaan, eu ainda vivo, mas tu, tu estás morto e tua cabeça me pertence", afirma a princesa, pouco antes de morrer, acrescentando ainda: "Posso fazer com isso o que eu quiser. Posso atirá-la aos cães e às aves no ar. Aquilo que os cães deixarem as aves do ar irão devorar..."21 (Wilde, 2014, p. 40, grifo nosso). Nessa fala violenta, a cabeça decapitada equivale aos resíduos de alimentos em uma bandeja que, após o festim diabólico, serão deixados à mercê dos animais. Como nas obras do artista francês Théodore Géricault, que no início do século XIX pintou diversos membros cortados, incluindo uma série de cabeças (Nochlin, 2001, p. 19), essa cena teatral parece amalgamar, inesperadamente, a violência das punições pela lâmina da guilhotina, a frieza objetiva da ciência, da observação clínica de uma peça na mesa de dissecação, e a angústia referida à ambivalência amor/morte expressa no romantismo melodramático.

- Figura 3 - Têtes d'exécutés (1818)

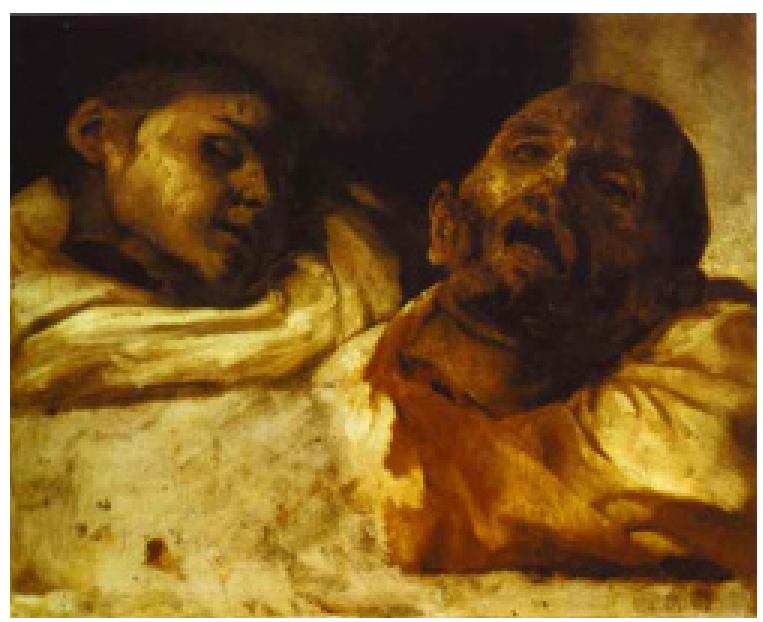

Théodore Géricault. Fonte: Biblioteca de imagens do National Museum, Estocolmo

É preciso destacar, ainda, um monólogo sinistro de Salomé dirigido à cabeça decepada do profeta: "Se tivesses me olhado, terias me amado. Bem, sei que terias me amado; e o mistério do amor é maior do que o mistério da morte" ${ }^{\prime 22}$ (Wilde, 2014, p. 40). Evidencia-se aqui a perigosa tensão entre amor e morte, aproximação que cativou o espírito europeu no final do século XIX. Em termos mais gerais, a obra de Wilde pode ser lida como um verdadeiro dispositivo de

21 No original, em inglês: "Well, Jokanaan, I still live, but thou, thou art dead, and thy head belongs to me. I can do with it what I will. I can throw it to the dogs and to the birds of the air. That which the dogs leave, the birds of the air shall devour..."

22 No original, em inglês: "if thou hadst looked at me thou hadst loved me. Well I know that thou wouldst have loved me, and the mystery of love is greater than the mystery of death". 
decapitações: há a "perda de si" dos personagens Salomé, Herodes e Narraboth, todos movidos pela paixão, por desejos desenfreados. É, porém, Jokanaan, figura mais consciente acerca dos perigos do olhar e das paixões, que literalmente perde a cabeça. Atraindo o olhar de todos e explorando esse fascínio, Salomé deixa de ser associada à lua e assume subitamente a força ofuscante da luz solar, degolando aquele que se recusa a mirá-la, para então recolher o inquietante benefício desse sacrifício: o beijo nos lábios de Jokanaan.

Ante o pedido da princesa e seu discurso beirando o grotesco, Herodes passa a temer que essa cena signifique um crime contra um Deus desconhecido: "Não irei mais olhar para coisas, não permitirei que coisas olhem para mim. Apaguem as tochas! Escondam a lua! Escondam as estrelas! Deixe-nos esconder no seu palácio, Herodíade. Começo a sentir medo"23 (Wilde, 2014, p. 41). Desde o início, a peça é um prenúncio de infortúnios associados ao regime do olhar. Para se proteger, o rei recorre à escuridão, furtando-se ao reino do visível. Sem estrelas, sem lua e sem luz, Herodes ouve a fala da princesa:"Ah! Eu beijei tua boca, Jokanaan, eu beijei tua boca. Havia um gosto amargo nos teus lábios. Foi o gosto de sangue?... Mas talvez seja o gosto do amor... Dizem que o amor possui um gosto amargo..." 24 (Wilde, 2014, p. 41). Também ele movido pelo desejo e pela paixão, Herodes condena à morte a sedutora dançarina, enfurecendo-se com o beijo na cabeça degolada do profeta, apagando definitivamente a luz lunar da cena teatral. Consumida pelo desejo, Salomé se torna vítima de seu próprio excesso.

Nessa cena violenta realizada no palco, Herodes apaga todas as luzes naturais e artificiais, pois havia se encenado aquilo que não podia sê-lo, uma cena que foge ao que o olhar humano pode suportar. Uma verdadeira e literal obscenidade. Assim como Jokanaan cobre a face para não ver Salomé25, Herodes cobre os olhos para não ver a cabeça decepada do profeta e, por fim, cobre os olhos dos espectadores, deixados no escuro diante da morte da princesa vingativa. A função especular do próprio mimético e a função apotropaica do espelho ganham então ampla dimensão na peça de Wilde, que atua como proteção ante pulsões desenfreadas, capazes de levar à violência e à morte. 0 espelho ficcional oferecido por Wilde não apenas reflete, mas serve sobretudo

23 No original, em inglês: "I will not look at things, I will not suffer things to look at me. Put out the torches! Hide the moon! Hide the stars! Let us hide ourselves in your palace, Herodias. I begin to be afraid".

24 No original, em inglês: "Ah! I have kissed thy mouth, Jokanaan, I have kissed thy mouth. There was a bitter taste on thy lips. Was it the taste of blood?... But perchance it is the taste of love... They say that love hath a bitter taste...".

25 Salomé relembra o momento em que Jokanaan se recusa a olhá-la, quando conversa com a cabeça decapitada: "Ah! Wherefore didst thou not look at me, Jokanaan? Behind thine hands and thy curses thou didst hide thy face" (Ah! Por que não olhaste para mim, Jokanaan? Atrás de tuas mãos e de tuas maldições tu escondeste teu rosto). 
de anteparo às forças destrutivas, aos perigos da iminente Grande Guerra quando caminhar ou dançar sobre campos embebidos no sangue de cadáveres mutilados seria o que, muito em breve, iria suceder na Europa.

\section{Referências}

BATAILLE, Georges. Soleil pourri. Documents n. 3: Hommage à Picasso, Paris, 1930. Disponível em: http://www.pilefacebis.com/sollers/IMG/pdf/Documents\%20 2-3\%20Hommage\%20a\%20Picasso.pdf. Acesso em: 10 dez. 2016.

CASTRO, Eduardo Viveiros. O medo dos outros. Revista de Antropologia, São Paulo, USP, v. 54, n. 2, 2011.

DELEUZE, Gilles. Lógica do sentido. São Paulo: Perspectiva, 2011.

FERRAZ, Maria Cristina Franco. Homo deletabilis: Corpo, percepção, esquecimento do século XIX ao XXI. Rio de Janeiro: Garamond, 2010.

Platão: As artimanhas do fingimento. Rio de Janeiro: Ediouro, 2009.

. Nove variações sobre temas nietzschianos. Rio de Janeiro: Relume Dumará, 2002.

FOUCAULT, Michel. História da sexualidade I: A vontade de saber. Rio de Janeiro: Edições Graal, 2006.

. História da sexualidade II: O uso dos prazeres. Rio de Janeiro: Edições Graal, 1998.

GIL, José. Metafenomenologia das invejas: magia e política. In: LINS; Daniel; PELBART

Peter Pál (Org.). Nietzsche e Deleuze - bárbaros, civilizados. São Paulo: Annablume, 2004.

JANES, Regina. Losing our heads. New York: New York University Press, 2005.

MARCUSE, Herbert. Eros e civilização. Rio de Janeiro: Zahar Editores, 1975.

MORAES, Eliane Robert. O corpo impossível. São Paulo: Iluminuras, 2012.

NIETZSCHE, Friedrich. A gaia ciência. São Paulo: Companhia das Letras, 2012.

NOCHLIN, Linda. The body in pieces. London: Thames \& Hudson, 2001.

PENNAFORT, Onestaldo. O festim, a dança e a degolação. Rio de Janeiro: Livraria São José, 1960.

PLATÃO. A república. São Paulo: Edipro, 2014. 
POE, Edgar Allan. O homem da multidão. In: Histórias extraordinárias. São Paulo: Companhia das Letras, 2008.

SENNETT, Richard. O declínio do homem público. Rio de Janeiro: Record, 2014.

SIBILIA, Paula. A nudez autoexposta na rede: Deslocamentos da obscenidade e da beleza? Cadernos Pagu, Campinas, n. 44, p. 171-198, jun. 2015.

O que é obsceno na nudez? Entre a Virgem medieval e as silhuetas contemporâneas. Revista FAMECOS, Porto Alegre, v. 21, n. 1, p. 24-55, jan./abr. 2014. DOI: https://doi.org/10.15448/1980-3729.2014.1.14753.

SINGER, Ben. Modernidade, hiperestímulo e início do sensacionalismo popular. In: CHARNEY, Leo; SCHWARTZ, Vanessa (Org). $\mathbf{O}$ cinema e a invenção da vida moderna. São Paulo: Cosac \& Naify, 2001.

VERNANT, Jean-Pierre. Com a morte nos olhos. Rio de Janeiro: Jorge Zahar Editor, 1988.

WILDE, Oscar. Salomé. South Australia: University of Adelaide, 2014.

Submetido em: 15/12/2016

Aceito em: 7/3/2017

Endereço das autoras:

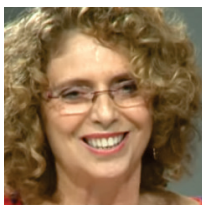

Maria Cristina Franco Ferraz <mcfrancoferraz@gmail.com $>$

Programa de Pós-Graduação em Comunicação e Cultura da Universidade Federal do Rio de Janeiro (ECO/

UFRJ)

Avenida Pasteur, 250 - Urca

22290-240 - Rio de Janeiro - RJ - Brasil

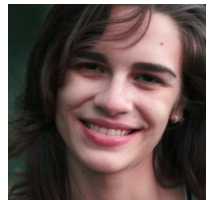

Louise Ferreira Carvalho < louisecarvalho1@hotmail.com>

Programa de Pós-Graduação em Comunicação e Cultura da Universidade Federal do Rio de Janeiro (ECO/

UFRJ)

Avenida Pasteur, 250 - Urca

22290-240 - Rio de Janeiro - RJ - Brasil 